Joseph Harris

\title{
Meet the New Boss, Same as the Old Boss: Class Consciousness in Composition
}

I argue that we need to acknowledge how the material interests of part-time and adjunct teachers, graduate assistants, tenure-stream faculty, and administrators can come into conflict in composition in order to negotiate fairly among them. I then call on bosses and workers in composition to form a new class consciousness centered on the issue of good teaching for fair pay. I discuss how the culture of academic professionalism militates against such a consciousness, and I propose three ways to forge a more collective view of our work: involving faculty at all ranks in teaching the firstyear course, devising alternatives to tenure as a form of job security, and pressing for more direct control over staffing and curricula.

\section{Comp droids and boss compositionists}

In a recent essay on the MLA Workplace Web site, Cary Nelson offers a despairing view of English departments filled with "comp droids" who have few of the intellectual interests of the professoriate but instead merely "beep and whir and grade, that's all." Nelson's aim is to denounce how we have allowed the job of teaching introductory English to become what economists call an "elastic commodity" - a position that requires little specialized training, with correspondingly low status and pay-and I think, to be fair, that he is trying to be

CCC 52:1 / SEPTEMBER 2000 
wittily empathetic in describing colleagues reduced to the status of droids. But to those of us working in composition, the joke is a stale one and even more annoying when it comes from a self-professed academic radical and advocate of labor in English studies. Droids are a management fantasy of the ideal workforce-docile, productive, faceless. And comp droids - that is, graduate teaching assistants, adjuncts, and part-timers-have for years provided the economic support for the work of senior faculty in English, both through teaching the introductory courses that such faculty no longer want to be bothered with and by enrolling in the graduate seminars that those professors have been freed up to offer instead.

Cary Nelson should know better. And so I want to give his misstep some emphasis, to note his use of droids as a reminder not only of the routine contempt that English still holds for intellectual work in composition, but also of the

\section{There have been few serious attempts to reconfigure who does what sorts of actual work in English departments, under whose supervision, under what conditions, and for what pay.}

willingness of the English professoriate to participate in the ongoing economic exploitation of composition teachers. While we have seen in the last two decades a flurry of proposals to recenter study in English around new or different sets of texts and issues-theory, cultural studies, global Englishes, teaching the conflicts, even composition and rhetoric-there have been few serious attempts (the 1986 Wyoming Resolution being a striking exception) to reconfigure who does what sorts of actual work in English departments, under whose supervision, under what conditions, and for what pay. Working as a comp droid in a department run by conservative New Critics is pretty much the same thing as working as a comp droid in one run by radical cultural theorists. What has occurred in such cases is less structural reform than a coup d'état. Meet the new boss, same as the old boss.

But I can't speak of bosses without admitting to the ambiguity of my own position. For I'm not a comp droid. I am, rather, a tenured professor and director of a university writing program; that is, I am what James Sledd, in his recent attacks on the politics and culture of our field, has called a boss compositionistthe faculty member assigned to supervise the droids. Sledd charges boss compositionists with selling out, suggesting that in exchange for faculty status for ourselves we have, in effect, agreed to make sure that the academic factory hums along efficiently in the interests of management-that is, of the tenured professoriate. He argues that the growth of composition studies as a field has failed to measurably improve either the teaching of writing or the status of 
most writing teachers. The only cause boss compositionists have really advanced, Sledd claims, is our own.

These are painful charges, but ones we need to take seriously. I come from a union family and am troubled by my position as a manager in a system that treats so many of its teachers unfairly. Despite that, I believe that good and necessary work goes on in the first-year writing course, work that gives a diverse range of students a stronger chance of succeeding in college than they might otherwise have. And so I am not willing, as some in our field have urged, to walk away from first-year composition, from its tangle of democratic hopes and bureaucratic requirements. What

\section{I am calling here for a new sort of class consciousness in composition, one that joins the interests of bosses and workers around the issue of good teaching for fair pay.}

I want to do here, instead, is to think through the conflicted class interests of many of us working in composition in order to see if some of the contradictions we face might be turned into opportunities for positive change. Our field has long been torn by the competing interests of researchers and teachers, of tenure-stream professors and tenure-less staff. We have been reluctant to talk about these tensions, though, preferring instead, as Julie Drew has pointed out, to speak in the voice of a "universal teacher-subject" (10) that elides real differences between academic ranks and working conditions. We need to admit to these conflicting interests in order to begin to negotiate more fairly between them. This doesn't mean that those of us who have gained roles as bosses should retreat from them, but rather that we learn how to use those positions of influence to push for changes in teaching and in the working conditions of writing teachers. I am calling here for a new sort of class consciousness in composition, one that joins the interests of bosses and workers around the issue of good teaching for fair pay.

\section{Class experience and class consciousness}

But first I need to say something about what I mean by class consciousness and why, in the context of our work as teachers and intellectuals, it proves a much harder thing to get (or, more accurately, to make) than one might at first think. In the opening pages of The Making of the English Working Class, E. P. Thompson argues that

class happens when some men, as a result of common experiences (inherited or shared), feel and articulate the identity of their interests as between themselves, and as against other men whose interests are different from (and usually opposed to) theirs. The class experience is largely determined by the productive relations 
into which men are born-or enter involuntarily. Class-consciousness is the way in which these experiences are handled in cultural terms: embodied in traditions, value-systems, ideas, and institutional forms. If the experience appears as determined, class-consciousness does not.... class is a relationship, and not a thing. $(9-11)$

This is a complicated but useful attempt to define class as something more than a demographic group or economic category. For Thompson, class is something that "happens," that one makes, chooses, asserts-"a relationship, and not a thing." Class consciousness rests on a sense of shared interests and not simply on a set of common experiences. This is why Thompson argues that the English working class had to be "made"-its interests articulated and its causes organized-in the nineteenth century.

Most approaches to class in composition, though, have focused on the autobiographical and experiential-treating social class, paradoxically, as a personal quality, an aspect of character. And so, for instance, the contributors to the recent anthology, Coming to Class: Pedagogy and the Social Class of Teachers, were asked by its editors to "trace the effects of their own class histories on their teaching" (vii). The result is a series of narratives that recount the difficulties faced by working-class students and teachers in moving into the middleclass world of the academy, often drawing attention to the subtler measures of cultural capital and class sensibility, to nuances of manner, gesture, taste, and style. But such stories also have the peculiar effect of always locating class in the past, as a way of talking about where someone has come from rather than about where they are now. Thompson doesn't slight the importance of social origins, "the productive relations into which men are born," but his concern is with how workers define their present interests and commitments. I'd like us to do the same. How might compositionists "feel and articulate the identity of their interests between themselves"? What social and material interests undergird our work as teachers of composition?

To ask the question this way is to immediately see how it is usually deflected into professional and disciplinary terms. Issues of class run just beneath the surface of our debates over disciplinarity, the status of part-timers and graduate assistants, the relations of composition and literature, composition and communication, teaching and research. But they have rarely surfaced in our journals and books. I think there are two related reasons why. The first has to do with the clumsiness of trying to use the traditional categories of class analysis - of capital and labor - to describe our work lives as professionals. The second concerns how the discourse of professionalism itself can subtly impede 
our attempts to form a sense of collective identity. Let me turn now, although somewhat indirectly, to these two problems.

\section{Proud to work for the university}

A few years ago I asked a group of beginning students at the University of Pittsburgh to list the terms they used to describe social class. Their first responses reflected a sense of class not as a set of competing interests but simply as a way of marking positions on a economic scale: upper, middle, lower. I pressed them for more, and got a series of not-quite synonyms: rich for upper, which most students agreed had slight pejorative connotations while still referring to something we would all gladly become, and poor as a mildly euphemistic version of lower with underclass as its more sinister counterpart. Middle stayed middleeven in the (once) steel town of Pittsburgh. And so, since the term clearly wasn't going to come from them, I decided to ask where the idea of a working class might fit into such a scheme, and several students quickly and politely responded by offering a completely different set of terms: capital, bourgeoisie, and proletariat. These were clearly terms they were familiar with from high school courses in social studies, if not from their own ways of talking about the world and their places in it, and they ran them off with the ready pleasure of getting the right answer on Jeopardy.

I was stumped. Then I asked: "Okay, what kind of job do you want when you get through college?" Some sort of profession was the quick consensus: a doctor or a lawyer, or at least someone who works in an office, who earns a salary rather than an hourly wage. As opposed to what? "Flipping burgers," was the immediate, laughing reply. What I began to realize was that these students were not unaware of class issues but rather that they were keenly, intuitively aware of facing a knowledge/service economy in which their choices were between jobs where they went out to lunch and jobs where they served somebody lunch. Few of these students, I think, actually entertain serious hopes of wealth; they simply hope to be comfortable. College is for them, as it has been for all of us, a means of entering a particular version of the middle class, what Barbara Ehrenreich has specified as the professional middle class - "all those people whose economic and social status is based on education, rather than on the ownership of capital or property" (12). Students come to college in the hope of entering the world of doctors, lawyers, administrators, teachers, professors, researchers, social workers, therapists, and clinicians. And our courses offer them ways of finding their places in the spectrum of professionals and managersof knowledge workers, not quite laborers, but not really capital either. But what 
we often fail to offer them (perhaps because we lack it ourselves) is a critical sense of belonging to this class, of whose interests the work of professionals might serve and how.

In her brief and moving essay, "Proud to Work for the University," the Pittsburgh writer Kristen Kovacic notes many of the confusions of growing up as a smart, ambitious kid from the working class. Kovacic describes how in the 1960s her father took on a job as an electrician at Carnegie Mellon University so that his children could later attend there for free. The university thus became part of her family's sense of identity. As Kovacic tells the story:

In those days we were required, on the first day of school, to say our names and what our fathers did for a living. One by one the kids would recite their names and then, simply, "J\&L" or “Homestead," or "Duquesne Works." I would wait my turn, and then somewhat haughtily announce, "My dad is an electrician at Carnegie Mellon University. I'm going to college there, free." I told people even when they didn't ask me. (20)

And so the distinctions, the class interests, among steel worker, electrician, and academic were blurred. Indeed, Kovacic writes of how it was not until she finally went off to college that she realized her family was working class:

In 1981 I arrived and began my Carnegie Mellon education. On my first day of my first class - a core curriculum sociology course-we read about the concept of class in American society. We learned how to identify the working class from the middle class; there were just a few simple rules. The working class, my textbook said, works with its hands, or, in the case of women, does clerical work like typing or filing. I did a little figuring. My mother is a secretary. My father is an electrician. His hands can get very dirty when he works, and he is scrupulous about washing them. He always carries Band-Aids in his wallet, ready for the daily cuts he gets at work, usually on his hands.

You can identify the working class, my textbook said, by the arrangement of their homes. The working class keeps its television set in the living room, for example, while the middle class keeps it in another place, like a den. I thought about our living room, Kathleen Mulcahy's vase crowning the television like a jewel. I thought, for the very first time, that I was working-class. It was a genuine surprise. (21)

The irony of only becoming aware of being part of the working class at the very moment that you are leaving it, of discovering your family figured as an example in a textbook, is one that, as the son of truck driver who also went off to an elite college, I have experienced along with Kovacic. I know of few moments that show more clearly the difference between what Thompson calls class ex- 
perience and class consciousness or that demonstrate how class consciousness is thwarted and confused in American experience. ${ }^{1}$ Why was class an operative category in Kovacic's sociology text but not in her own life? In part because the dream of education, of moving up, mystified the competing interests of her family and the corporation her father worked for, made her family seem merely lower-middle rather than working class. And, indeed, as Kovacic tells the story, finding out the meaning of which room the television gets put in was not the point at which she really understood the dynamics of class. That came laterwhen shortly after she graduated, the university, as a cost-cutting measure, laid off her father and two-thirds of his coworkers.

I asked the students whom I had talked with about burger-flipping to respond to Kovacic's essay and also to say something about how they would describe the social class of their own families. Here is what some of them wrote:

I would put my family in the middle class. I must specify as being lower middle class. We are middle class because we have a modest house, not paid for yet. We have two cars, both from the 80s, neither being luxury or sporty. My father's job is not secure because of plant closures. My mother does not work. We are not poor because we do enjoy some luxuries, i.e., TV, VCR, eating out every one in a while.

The article made me mad because the valedictorian's dad reminds me of my dad. Not because my dad was an immigrant, but my dad signed on to a factory hoping for a decent existence and a non-comfortable but peaceful retirement. This is in jeopardy and it angers me deeply. It angers me that people (my father and others), who work hard and who know more about machinery and the factory than the college-educated engineers who make twice as much, are treated like garbage. I only hope that I can do something on the level of valedictorian of CMU to make my dad proud.

$$
* * * * *
$$

I would classify my family's social class as upper middle class. I know this because my father makes enough money to support my mother, my two sisters and brother and to pay half of my college for me. We are never in need, and we can afford to get what we need. We also own a house with a pool and a condo in Myrtle Beach.

$$
* * * * *
$$

Hmmm, what class am I? I'm not sure what the official cut-offs are, but I would venture a guess that I'm middle class. My dad worked for IBM from the time I was born to the time I was about 12 and my Mom stayed at home with me and my brother until I was 14. When I was 12 my father was laid off by IBM and bounced between jobs for about 3 years. Fortunately, he now works at IBM for another company. My family enjoys a few luxuries (i.e. a couple of televisions, can afford a vacation every once in a while, etc.) and we make a comfortable living, so I guess that puts us right in the middle class. We keep our heads above water and that's good enough for me. 
There is a modest, nuanced, and likeable quality to each of these passages. Although all three writers describe their families as middle class, each hints at a slightly different set of pressures and tensions. In almost the same phrase, the first writer tells both of his anger at the "college-educated engineers" who lord it over his father and of his hopes to make his dad proud of his academic work. The family of the second writer seems more affluent than the others, with their pool and condo, but even here the father is described as only able to pay half of the tuition to a public university. And while the family of the third writer has kept their "heads above water," doing so has required his dad to bounce from a job where he worked for IBM to one where he now works at it. In sum, while all three families are described as middle class, none are pictured as secure. Indeed, one can guess that these students have come to college, in part, less to jump ahead than to maintain a position in the middle, to ward off the specter of burger-flipping.

A quick note on prepositions: While I don't know exactly what the third writer here is getting at when he stresses that his father now works at rather than for IBM, it could be that his dad is now Academics usually speak of themselves as an outsourced worker, without the teaching at a university or in a program or benefits or job security given "regular" department - a phrasing that suggests we keep a employees. Kovacic writes of her fameasure of control over the work we do, that our ther, the electrician, that he was "proud labor is not directly"for" our employers. to work for the university." As the biographies attached to our books and articles attest, however, academics usually speak of themselves as teaching at a university or in a program or department-a phrasing that suggests we keep a measure of control over the work we do, that our labor is not directly "for" our employers. It's worth remembering, though, that many of our fellow writing teachers work "at" the university in the weak sense of the term-as contingent labor, on a per-course basis, without benefits or job security, or even, in many cases, much say over the content of what they teach.

\section{Cultural capital and the fear of falling}

And so the class position that most of us hold, and that students aspire to, turns out to be more complex and uneasy than it might at first seem. For what the professional middle class possesses is not economic but cultural capital, a set of skills and knowledges - and college is where one comes to acquire such capital. In Distinction: A Social Critique of the Judgement of Taste, Pierre Bourdieu links these two forms of capital and shows how what might seem to be matters 
of individual temperament or skill can be traced instead to membership in a certain social class - and I think that anyone who has taught a basic writing course, or who has worried about what school district to buy a home in, has felt this connection. Indeed, for Bourdieu, one of the main functions of schooling is to legitimize a set of social differences by making them appear the results of aptitude and effort rather than class. But in Fear of Falling: The Inner Life of the Middle Class, Barbara Ehrenreich gets at something that Bourdieu's brand of determinism misses, noting of the professional middle class that

Its only "capital" is knowledge and skill, or at least the credentials imputing skill and knowledge. And unlike real capital, these cannot be hoarded against hard times ... [but] must be renewed in each individual through fresh effort and commitment. In this class, no one escapes the requirements of self-discipline and self-directed labor; they are visited in each generation, upon the young as they were upon the parents. If this is an elite, then, it is an insecure and deeply anxious one. (15)

Nowhere is this fear of falling better evidenced than in academia, which, through the prolonged hazings of graduate school and tenure and its endless reviews of who really has the right stuff or not, keeps many of its members in a state of economic and emotional uncertainty well into midlife. What this anxiety could usefully encourage is a skepticism towards the claims of a supposed meritocracy that so relentlessly divides us into stars and "wannabees," master critics and token professionals, bosses and droids. ${ }^{2}$ But for that to happen, we will first need to admit that we are indeed workers in a corporate system that we hope to reform, rather than persisting in fantasies of escaping that system, of

We ... need to admit that we are indeed workers in a corporate system that we hope to reform, rather than persisting in fantasies of escaping that system, of operating in some pure space as critics who may happen to work at a university but who are somehow not of it. operating in some pure space as critics who may happen to work at a university but who are somehow not of it. In his new book, As If Learning Mattered, Richard Miller shows the enduring appeal of this vision of the intellectual as an outsider, a detached observer, arguing that this professional myth has consistently led to a denial of the actual conditions and uses of most academic work. ${ }^{3}$ Miller closes his book with a call for imagining ourselves not as critical aliens but intellectual-bureaucrats, workers in a collective educational project. But almost all the routine forms of marking an academic career-CVs, annual faculty activity reports, tenure and promotion reviews - militate against such a view of our work by singling out for merit only those moments of individual "productivity," the next article or grant or graduate course, creating a version 
of professional life that oddly yet almost seamlessly merges the roles of subaltern dissident and intellectual entrepreneur. The structures of academic professionalism, The structures of academic professionalism, that is, encourage us not to identify with that is, encourage us not to identify with our our coworkers but to strive to distinguish coworkers but to strive to distinguish ourourselves from one another-and, in doing selves from one another-and, in doing so, to so, to short-circuit attempts to form a sense short-circuit attempts to form a sense of our of our collective interests and identity. collective interests and identity. To better understand this social dynamic, let me turn now to one of the great observers of class relations, the novelist Henry James.

\section{The anxious governess}

In A Rhetoric of Motives, Kenneth Burke suggests that social ambitions often get re-presented as sexual drives and hints that James' The Turn of the Screw might be read not only as a disguised tale of repressed hysteria (as is by now common) but also for its insights into class envy (215). The nameless governess in James' story is, of course, in genteel yet straitened circumstances, "the youngest of several daughters of a poor country parson" (4). She answers an advertisement placed by a London bachelor who is hoping to find someone to relieve him of the responsibility of actually attending to a young niece and nephew whose care has fallen to him. The young woman is immediately "carried away" (8) by this rich and insouciant uncle, who

struck her, inevitably, as gallant and splendid, but what took her most of all and gave her the courage she afterward showed was that he put the whole thing to her as a kind of favor, an obligation he should gratefully incur... She hesitated-took a couple of days to consult and consider. But the salary offered much exceeded her modest measure, and on a second interview she faced the music, she engaged. (4)

When the governess arrives at Bly, it is clear that she identifies herself wholly with her patron. Indeed, of the seven other servants at the country house, only one even merits a name in her story, and that is Mrs. Grose, the housekeeper, a "stout, simple, plain, clean, wholesome woman" (7) whom the governess treats with unwavering condescension. For despite her economic circumstances, the governess feels herself the social equal not of her coworkers (or even of her pupils) but of the absent uncle on Harley Street. Her cultural capital makes her a fit match for his income, or so she feels:

It was a pleasure ... to reflect that by my discretion, my quiet good sense, and general high propriety, I was giving pleasure-if he ever thought of it! - to the per- 
son whose pressure I had responded. What I was doing was what he had earnestly hoped and directly asked of me, and that I could, after all, do it proved even a greater joy than I had expected. I daresay I fancied myself, in short, a remarkable young woman and took comfort in the faith that this would more publicly appear. (15)

Who appears, of course, is not her patron from Harley Street but the apparitions of his sexualized double, Quint, and her rival, the former governess, Miss Jessel. Post-Freudian readers of James's novel have for some time now been inclined to view the two ghosts as expressions of sexual longings that the governess cannot consciously admit to, but I would also point to how this poor but "remarkable young woman" of "general high propriety" continually defines herself as belonging, on the grounds of her education, to a higher social class than her fellow servants - both quick and dead. After she first catches sight of Quint on the tower, for instance, the governess tell Mrs. Grose that he looks like an "actor" in "somebody's clothes"-or, at least, what she would "suppose" an actor, which she's never seen, might look like (23). In any case, Quint is nothing like the gentleman she saw in Harley Street; that much the governess is sure of (16). But the most telling moment comes when she first comes upon the apparition of her rival, the former governess, Miss Jessel, seated-where else?in the children's schoolroom.

Seated at my own table in clear noonday light I saw a person whom, without my previous experience, I should have taken at the first blush for some housemaid who might have stayed at home to look after the place and who, availing herself of rare relief from observation and of the schoolroom table and my pens, ink, and paper, had applied herself to the considerable effort of a letter to her sweetheart. (57-58)

But when this (seemingly) semi-literate "housemaid" stands and returns her gaze, the governess realizes that she is actually the ghost of her "vile predecessor" who "looked at me long enough to appear to say that her right to sit at my table was a good as mine to sit at hers" (58).

This is a remarkable scene, and the analogy to academics doesn't seem hard to draw. We don't own capital, but we identify with it-at least in the disguised form of culture and learning. That schoolroom table is ours. And the comparisons to the situation of writing teachers are particularly acute. One might say that the governess sees herself as working at Bly but not for it-at least not in the same way that Mrs. Grose and the other servants do. She is an upstairs version of Susan Miller's "sad woman in the basement" (121-41), doing the dirty work of high culture, deciding who gets to sit where, judging the 
"considerable efforts" of others at writing-and all the while forgotten in Harley Street. It is a suggestive parable, and, indeed, much more could be done with the role of writing as a class marker in The Turn of the Screw: The tale is itself presented as a manuscript written by the governess "in old, faded ink, and in the most beautiful hand" (2); a key plot mechanism is that only the governess can communicate with the uncle (since the eponymous Mrs. Grose cannot write and the children must have their letters vetted and mailed by the governess), and the narrative is filled with letters-both mailed and received, stolen and found, some anxiously read and others disregarded. My point here, though, is simply to note how the governess's identification with a superior social class helps blind her to both her own best interests and those of her young charges. She is seduced by her patron and the vision of London, wealth, and refinement that he offers her. My worry is that a similar desire to be part of a cultural or critical vanguard might also block our attempts to recognize our own interests and those of the students we work with, that composition may be seduced by a narrow vision of professionalism.

\section{The seductions of professionalism}

In saying this, I am echoing the words of Jeanne Gunner, who has described the failed series of attempts to reform the working conditions of writing teachers that followed the 1986 Wyoming Resolution as "a history of professional seduction." It has taken me several years to come to understand the charges that Gunner makes in her essay, and so in turning back here to the class politics of composition, I want to begin with a disclaimer. In the 50-year history of CCCC, there seem to me two truly heroic moments, points where the members of our field spoke out of our strongest intellectual convictions and concerning our most deeply felt responsibilities. The first was the 1974 endorsement of the Students' Right to Their Own Language; the second was the work that came out of the 1986 Wyoming Resolution. It is worth noting that it has only been in the last few years that organizations such as the MLA ("Final Report") and ADE ("Report of the ADE") have begun to seriously address the problem of working conditions-and indeed it was in thinking through why I was troubled by aspects of their recent statements that I began to understand how CCCC had made some of the same tactical mistakes in its own, pioneering attempt to remedy the working conditions of writing teachers, the 1989 "Statement of Principles and Standards for the Postsecondary Teaching of Writing."

The difficulty that I see with the recent MLA and ADE discussions of working conditions stems from their focus on the professional status of faculty 
in introductory courses rather than on the forms of support and training offered to all teachers of writing. The limits of such an emphasis are made clear in a brief essay ("Setting Standards") in the MLA Newsletter by Phyllis Franklin, the Executive Director of the MLA. In this piece, written in response to a charge from the MLA delegate assembly, Franklin proposes a set of ideal percentages for staffing introductory writing courses. But she also goes to some

To view the problem as simply a matter of limiting the percentage of part-time teachers used - without first addressing the working conditions of all writing teachers - seems to me to miss the point. length to suggest the problem of thinking in such terms when she reports on a conversation she had with Judith Eaton, the president of the Council for Higher Education Accreditation. What Eaton told Franklin was that

The problem is not that some teachers work part-time. What matters ... is the conditions under which they work. If institutions took the same care in hiring part-time teachers that they take in hiring full-time teachers, paid part-time teachers to perform the same administrative functions outside the classroom that full-time teachers are expected to carry out, and supported professional development and access to institutional resources for all faculty members, would using large numbers of part-time teachers be different from using large numbers of full-time teachers? (qtd. in Franklin 5)

Or, to phrase the issue another way: What would be an "acceptable" level of use of underpaid, under-supported, and overworked teachers? Forty-five percent? Ten percent? Zero? While I support the goal of involving more tenure-stream faculty in teaching undergraduates, to view the problem as simply a matter of limiting the percentage of part-time teachers used-without first addressing the working conditions of all writing teachers-seems to me to miss the point.

This is much the same criticism that Gunner, Sledd, and others have made of the CCCC "Statement of Principles and Standards" - that it ended up disenfranchising the very teachers that the Wyoming Resolution had aimed to support, that what had begun as an attempt to speak out against the exploitation of part-time teachers of writing turned into an argument for the disciplinary status of research scholars in composition studies. On the face of it, this argument seems odd, since over half of the text of the 1989 CCCC statement details the forms of support that part-time and adjunct teachers need in order to do their jobs well, listing a set of standards concerning class size, office space, clerical help, and opportunities for professional growth that we need to continue to press for. The problem has to do with the CCCC statement's uncritical embrace of the tenure system as a guarantor of good teaching. In effect, the statement argues 
that, so long as we have part-time teachers, we need to treat them well, but what we really want is for composition to be taught by tenure-stream faculty. This is the seduction that Gunner speaks of, the belief that the system can correct itself, that composition can somehow become part of what English professors routinely study and teach - and thus that the need to maintain small armies of contingent instructors to staff first-year writing courses will eventually disappear.

This is an alluring fantasy, but one that shifts attention away from present and real labor practices - who does what work for what pay - and towards questions instead about the potential disciplinary status of composition in the future. And, indeed, recent attempts to define a place and identity for composition have spoken much more to scholars than

I am less worried, that is, about the status of composition as a discipline than about whether composition programs treat instructors fairly and teach undergraduates to write well. teachers-with Maxine Hairston exhorting us to "break our bonds" with literary studies, David Bartholomae countering that we need to continue "to acknowledge our roots in English" (49), and Sharon Crowley recently urging us to renounce our "ethic of service" (250). But while I, too, am concerned with how scholarly work in composition gets valued (or not), the crucial questions for me are still these: Who does the actual teaching? What institutional structures best allow us to shape how writing gets taught to undergraduates? I am less worried, that is, about the status of composition as a discipline than about whether composition programs treat instructors fairly and teach undergraduates to write well. Following Gunner and Sledd, I have come to believe that we have succumbed to a professional logic in which establishing composition as a research field is seen as the key to improving the teaching of writing to undergraduates. But there will never be close to enough tenurestream compositionists to teach all the sections of first-year writing offered at U.S. colleges and universities each year; indeed, there will never be enough English professors to do so. ${ }^{4}$ The tenure system has done little to prevent the exploitation of part-time teachers of writing - and simply granting tenure to a few more Ph.D.'s in rhetoric and composition each year won't fix that problem. Both Michael Murphy and Richard Miller ("Let's Do the Numbers") have urged us to move beyond our seeming fixation on the Ph.D. and the availability (or not) of tenure-stream jobs and instead to agitate at a local level for better working conditions for the people actually teaching writing. I agree. We need to find ways now of supporting good teaching for undergraduates and fair working conditions for teachers-including, for instance, post-doctoral fellowships, full-time non-tenure-track instructorships, and long-term contracts for adjunct faculty. ${ }^{5}$ 
Let me quickly say that this is not an argument against scholarship in composition. I think remarkable work is going on in composition studieswork that should be promoted both because of its intellectual interest and because the individuals who run composition programs and train writing teachers need the security and leverage of tenure. My point is that we need to distinguish between questions of disciplinary status and working conditionsthat the two issues are connected but not identical. I am also not arguing against professionalism in teaching. Here I may disagree somewhat with Gunner and Sledd, who both suggest that one of the best ways of demonstrating a commitment to teaching writing is simply by doing it year after year. But teaching a course in a routine manner for years is not, I think, a strong argument for being allowed to continue to do so. In return for better working conditions, we need to insist that teachers in our programs keep up with new work in composition and that they revise their practices in the light of their reading.

In the February 1989 issue of $C C C$ - the same issue that contained both the draft version of the CCCC Statement and Bartholomae's call for composition to remain in English-another essay by Gary Olson and Joseph Moxley reported on the "limits of authority" placed on directors of composition programs in English departments. Olson and Moxley offer a very different version of what it might mean for composition to be "in" English than Bartholomae did, focusing not, as he does, on "problems of thinking, problems of teaching" (49), but rather on who has actual control over the staffing and content of writing courses. And what they found, in a survey of 136 English department chairs, was that the director of composition in many schools has little real say over program policies or staffing, but rather is assigned to work with a set of graduate assistants or part-timers whom others have chosen and to administer a curriculum that others have designed.

Here is where the interests of composition workers and bosses might come together. What the director of a writing program wants, it seems to me, is to be able to interview, hire, and train a teaching staff, to fire teachers who don't work out, to establish curriculum, to set policies, and to represent the program as he or she sees best. What teachers want are reasonable salaries, benefits, working conditions, and job security; autonomy over their work; and to be treated with respect as colleagues. All of us want to provide the best teaching possible for undergraduates. But the treatment of writing teachers in English departments has been a scandal for years, while the authority of composition directors has been consistently compromised to suit the needs of English graduate programs and faculty. It thus seems in our joined interests as composition 
workers and bosses to press for more direct control over our curricula and staffing - within departments of English or, if need be, outside them.

Sharon Crowley has called on compositionists to renounce our "ethic of service" in order to claim full status as a research discipline. My question is: Service to whom? I am happy to imagine my work

It thus seems in our joined interests as composition workers and bosses to press for more direct control over our curricula and staffing - within departments of English or, if need be, outside them. as a service to undergraduates, but I am not interested in managing an employment service for graduate programs in English studies. We need to distinguish between service to undergraduates and service to professional special interests - and, when pushed to choose, to be willing to side with the needs of undergraduates and their teachers. In the last 30 years the teaching of writing has been theorized in powerful and competing ways, and composition studies has been established as an exciting, interdisciplinary field of research. I would like to see us turn more attention now to the institutional structures in which we work, to press for a stronger authority for composition directors and a greater autonomy for first-year writing programs. Doing so will not dissolve the real conflicts and tensions between workers and bosses in composition, but it will at least offer us ways of addressing them.

\section{The labor of composition}

So how, as boss compositionists, might we both identify our interests with those of the teachers working under our supervision and, at the same time, gain more control over our undergraduate programs? I think a key first step is simply to teach in the courses we supervise. At the start of the 1998-99 school year, I came across a news article describing the outraged (but, of course, ineffectual) response of tenured faculty at an eastern state university when they were informed that their school would be contracting out to Sylvan Learning Systems to provide remedial instruction in mathematics. The reason the faculty's response was so easy to disregard was that, despite their stated concern for quality of instruction and the integrity of the liberal arts, it turned out that very few of the tenure-stream faculty were involved themselves in teaching the remedial and introductory courses that were being subcontracted to Sylvan. As one professor put it, "In the end, it came down to the idea that since most of us weren't teaching these courses anyway, how much should we say?" (Schackner E8). This seems to me very close to the situation of English faculty at presentat least at most state and research universities. We have abandoned a key part of our curriculum, basic and first-year writing-one of the few things we do 
that anybody outside of English cares anything about-to an army of largely underpaid, under-trained, and under-supported teaching assistants (TAs), part-timers, and adjuncts. We have said, in effect, that almost anybody who enrolls in a graduate program in English can teach-at reduced salary-the courses that make up the bulk of our undergraduate enrollments. (This is what Cary Nelson means when he says that the English professor has become an "elastic commodity.") And then we feign surprise when new Ph.D.s in English find it hard to find the jobs they thought they were training for, or when deans balk at replacing retired medievalists or relocated postcolonial theorists.

But the social costs are more grievous. If open admissions is threatened at the City University of New York, then that is in strong part because the tenurestream faculty at CUNY failed to involve themselves centrally in the teaching of basic and remedial courses. Getting rid of basic writing programs in New York involves, for the most part, cutting the jobs of adjuncts, not tenured faculty. Similarly, the recent outsourcing of basic writing instruction at several University of California campuses was made easier because so many basic writing teachers already worked on a per-course basis, and so they could

We have abandoned a key part of our curriculum, basic and first-year writing - one of the few things we do that anybody outside of English cares anything about - to an army of largely underpaid, under-trained, and under-supported teaching assistants (TAs), part-timers, and adjuncts. readily be made adjunct instructors at community colleges rather than adjunct instructors at University of California campuses-teaching much the same course to similar students but in worse conditions for less pay. ${ }^{6}$

But while it is tempting - and not inaccurate - to decry "conservative politicians" and "cost-cutting administrators" for such moves to dismantle access to higher education, much of the real blame remains ours. A friend of mine told me a story a few years ago about an incident that occurred when she was the acting chair of her department. It turns out that one of the part-time instructors hired to staff their first-year writing course simply disappeared in the middle of the fall term, just stopped showing up for class. The students gave the instructor two or three weeks and then decided to go to the chair (my friend) to complain, rightfully, about the loss of time, money, and learning that their instructor's absence had cost them. (It was at that point too late in the term to try to find someoneanother adjunct, no doubt-to finish out the course.) As one of the students angrily told my friend: "I want full credit and I want my money back."

This remark has stayed in my mind for several years, and I think I have finally figured out why I find it so telling. For what that student had done was to 
ventriloquize the attitude of English towards composition in all its unconscious self-righteousness. For English does want full-credit for teaching composition, does want the full-time equivalents and graduate teaching assistantships and ethos of collegial responsibility that come from such work. But English doesn't want to pay for it. This situation has led to a multi-tiered workforce in which a

English does want full-credit for teaching composition, does want the full-time equivalents and graduate teaching assistantships and ethos of collegial responsibility that come from such work. But English doesn't want to pay for it. dwindling number of tenure-stream faculty teach courses for majors and graduate students, and those same graduate students (or ex-graduate students) teach the introductory courses that the tenured faculty have abandoned. This is a familiar diagnosis of our present dilemma, I realize. What I want to emphasize, though, is that this situation profits not only faceless administrators and conservative legislators but also tenure-stream faculty in English-who now not only don't have to teach first-year writing but also are given a steady supply of students for those advanced seminars they $d o$ want to teach in the very graduate students who have been recruited to their programs and conscripted to staff composition. It is, in its own way, a marvelous feedback loop-and one in which one of the main tasks of the director of composition is to make sure that things go smoothly enough at the introductory level that the tenured faculty never have to be bothered with it again. The only people who lose out are undergraduates and their teachers.

But if this is a situation that we (that is, tenure-stream faculty in composition and English) have helped to construct (to our own advantage), then it is also a situation we can help fix. Whether we have the will or courage to do so, I don't know, but here's what I think needs to be done: (1) We need to push to improve the working conditions of all teachers of writing; (2) we need to reconfigure the first-year course in writing in order to lessen the demands it places on staffing; and (3) we-tenure-stream faculty in composition and English-need to regularly teach first-year writing. Let me discuss these proposals in order.

\section{We need to improve the working conditions of all teachers of writing}

There is a clear ethical imperative for us to make sure that our colleagues are paid fairly for their work, but there is also just as clearly a self-interested reason: We don't want a large workforce of contingent, per-course laborers exerting downward pressure on our own salaries and job security — which is exactly what is happening now. If four sections of a course can be staffed with part-timers for 
roughly the same amount it costs to pay a tenured faculty member to teach just one, and if the profession not only fails to object to such staffing but actually encourages it through its system of professional rewards, then there will inevitably be more part-timers and fewer tenured faculty as the years go by. (Both Murphy and Miller "do the numbers" that support this argument.) We thus need to work to decrease the economic incentives for colleges and universities to employ parttimers through agitating for reasonable salaries, benefits, and job security for all teachers of writing. This task is difficult but one that I think is possible through the use of collective bargaining, the consolidation of part-time positions into full-time non-tenure-track positions, and the linking of tenure-line hires to a faculty commitment to teaching introductory courses.

Tenure-stream faculty must also be willing to make the case for improving adjunct pay and working conditions a priority. More travel money for faculty? Let's address the part-time issue first. Reduced course loads? Let's address the part-time issue first. An extra tenure-stream line or funds for visiting lecturers? Let's address the part-time issue first. When the faculty begin to take such stands - that is, to materially identify our interests with those of our part-time colleagues - we will have begun to move beyond the liberal hand-wringing that now characterizes our talk about the part-time problem.

But better pay and conditions for adjunct faculty would also require us to insist on their ongoing professional development and on higher standards for their work as teachers. Improving working conditions needs to be posed not simply as a labor issue but also as a means of improving the quality of undergraduate education. We cannot just pay part-timers more and then hope that this added income will somehow improve their teaching. We need, rather, to be willing to make the training, supervision, and review of adjunct instructors part of our own regular work as faculty. And the case I have made here for improving the working conditions of adjunct faculty also goes for graduate teaching assistantsImproving working conditions needs to
be posed not simply as a labor issue but
also as a means of improving the quality
of undergraduate education. with one reservation. I support the case for viewing graduate TAs as employees of the colleges and universities they work for-entitled to fair pay, benefits, and bargaining rights. But I also feel that TAs should be then interviewed, hired, and evaluated as employees-that is, on the basis of their work as teachers. A graduate fellowship should not be a sinecure for a poor or indifferent teacher. One should be required to demonstrate a clear ability (or, at the very least, a strong promise) to teach writing in order to be granted a fellowship to do so, and ineffective teachers should risk losing their support. 


\section{We need to reconfigure the first-year course in writing in order to lessen the demands it places on staffing}

Much recent talk about the staffing of the required first-year course in writing has been marked by an inexact and yet telling analogy with the discourse of slavery. For several years now there have been calls for the "abolition" of the required first-year English course-proposals that often seem to desire to get rid of the field hands in composition while somehow retaining the more leisured status of the bosses in the main house. ${ }^{7}$ This

What we can no longer do is simply require students to take a course that tenure-stream faculty lack the interest or ability to teach, appoint someone as director of composition to handle the resulting logistical nightmare, and then forget about it. return of the repressed points to the ongoing economic dependence of composition programs (and thus English departments) on a large, subordinated workforce. For if first-year composition is to be required of nearly all students, and if it is to be taught in small sections, then there will always be a demand for large numbers of writing instructors-far more than most big universities are willing to pay fair wages for. We thus need to consider how to lessen the demands placed on staffing by the first-year course. One way of doing so would be to make first-year composition elective rather than required-as Crowley and others have urged. But there are other options. We might supplement the first-year course, for instance, with seminars involving writing taught by faculty across the disciplines. Or we might devise ways of helping students with sentence-level issues in writing through imaginative uses of peer tutors and writing center consultants. ${ }^{8}$ Or we might experiment with forms of directed self-placement, so that students who really feel that they can do without basic writing or composition are allowed to take that chance. ${ }^{9}$ But whatever we do, we also need to make sure that we don't unintentionally close down access to higher education that courses in basic writing and composition have helped open up-that students can get the help they need with their writing from qualified instructors. (Ironically, that may often not be the case when students are required to take courses from an overworked and under-trained staff.) I don't have a specific set of wholesale changes in mind here; rather, I'd hope for small, local, tactical revisions to present structures. But what we can no longer do is simply require students to take a course that tenure-stream faculty lack the interest or ability to teach, appoint someone as director of composition to handle the resulting logistical nightmare, and then forget about it. This leads me directly to my last proposal. 


\section{We-tenure-stream faculty in composition and English-need to regularly teach first-year writing}

When I have made this argument at other times and places, this is the proposal that has provoked the most objections. I find this response alternately amusing and depressing, since, unlike reforming working conditions or the curriculum, this issue is entirely under our control. We could do it next term - that is, each of us could sign up to teach a section of basic or first-year writing-and if we did so, the English department as a workplace would be profoundly altered. We all know the arguments against doing so-senior faculty are needed to teach other "more important" courses in the major; faculty are no longer able or willing to teach writing; they are needed to mentor graduate students (the ones who can no longer get jobs) ... and so on. Or to return to words of that tenured radical, Cary Nelson:

Although I have taught composition and enjoyed it, I would now find it demoralizing and intolerable to have to grade hundreds of composition papers each semester. There is no way I could do it as carefully and thoroughly as my graduate students do. ("Lessons" 21)

And so, with his uncanny knack for voicing the collective unconscious of the profession at the very instant he is trying to critique its practices, Nelson here returns composition to its "natural" teachers: the young, the ambitionless, the saintly, those with no other choices, and, of course, the droids-all of whom do the job so "carefully and thoroughly" that professors such as Nelson no longer need to be bothered with the chore.

I have two, competing responses to those of my colleagues in English who, like Nelson, find the idea of teaching composition "demoralizing and intolerable." On the one hand, I want to speak to them as a fellow professional, to say: "It's not at all what you think. There are ways of teaching writing that have a real intellectual interest and energy. I've taught it with increasing pleasure for years and plan to do so for years more. Join me." But, on the other hand, there is part of me that wants to speak not only as a colleague but as a taxpayer and parent, to tell them: "I don't care how demoralizing you think it is. It's your job. Shut up and do it."

But let me for now stick with the more politic, collegial response. How might we encourage more English professors to teach first-year writing? I think we will need to make four moves: First, we need to persuade our colleagues that work in first-year writing can be intellectually engaging. We need to find ways 
to circulate the work that compositionists have done in rethinking the teaching of writing outside the boundaries of our field. Second, to have an impact on the life of a department, this work cannot be limited to the efforts of individuals, but must instead be made into a collective project, a means of bringing several faculty together to work at a new location in the curriculum. Third, we need to acknowledge that teaching writing is indeed a time- and labor-intensive activity, and thus to make sure-through variable workloads for faculty, caps on class size, and the like-that work in composition can be a part of someone's career without subsuming his or her other interests. And, fourth, we need to continue to press for teaching (and writing about teaching) to be viewed as a form of intellectual work on equal terms with traditional scholarship in literature, rhetoric, and theory. ${ }^{10}$

\section{From the social to the material}

I return to the question of class consciousness. I agree with Michael Murphy when he argues that the "very existence" of part-time instructors is for "many in composition a professional embarrassment, compromising the standing of composition within the community of academic disciplines" (26). I have read this attitude as symptomatic of a fear of falling among compositionists, of a desire to seem not service-workers but scholars. One reason why composition programs remain in English departments is because so many compositionists self-identify with the professoriate in English, especially with its graduate faculty. I believe we need to move in the opposite direction, that if compositionists have any chance to effect change in the academy-and I think we do-it is through identifying our interests with those of teachers of basic and first-year writing. I have tried here to suggest

If compositionists have any chance to effect change in the academy - and I think we do - it is through identifying our interests with those of teachers of basic and first-year writing. some ways of doing so: teaching in the first-year course, devising alternatives to tenure as a form of job security, pressing for more direct control over staffing and curricula. It is through turning our attention to the ways in which our day-to-day work-with students, colleagues, parents, administrators-gets structured that we might begin to create a new class consciousness for our field. Several compositionists have already begun to do so, pushing past a by now familiar but still fairly abstract concern with the "social" to a more detailed analysis of the material constraints on our work: not only Miller and Murphy, but also Mary Soliday (“Class Dismissed”), Tom Fox, Bruce Horner, and Eileen Schell. But as much as I admire this new materialist 
and activist scholarship, the real gains still need to be made, as it were, on the ground, in our programs and departments.

A while ago I had the chance to watch a couple of Stephen Seagal movies with the teenaged son of one of our friends. A little to my surprise I found that I liked the movies a lot. They're remarkably clean cut, wholesome, and moralistic. Seagal is consistently portrayed as someone who's had his share of troubles, but who trains hard, treats women right, and sticks by his word. He does indeed kick much ass, usually while fighting against impossible odds, but the action is extraordinarily stylized and choreographed and, more importantly, Seagal always fights on the side of the good, and he always wins. The high point of the movies came for me at a point when Seagal and his sidekick are holed up together in a hotel, readying themselves for one last battle against a crowd of villains who are waiting for them in the street below with automatic rifles, pistols, rocket launchers, knives, bolos, and the like. Seagal and his buddy are, of course, unarmed. Daunted, the friend asks: "How we gonna make it?" Seagal stares icily back and replies: "Superior training. Superior mental attitude."

Since then that phrase has become a kind of ironic mantra in my household. Check for the mortgage bounced? Superior training. Superior mental attitude. Both kids are sick and both of us have meetings at nine? Superior training. Superior mental attitude. It seems to me that reformers in English and composition have also adopted this attitude, but without the irony-that we too often speak as if we can solve problems that are structural and economic in nature by working yet some more on our training and mental attitude: revising reading lists, drawing up new proposals for graduate programs, drafting manifestos for new kinds of rhetorical study, and so on. My argument here has been that if we want to effect real change we need to begin by contesting the routine and invidious divisions of labor in our own programs and departments. Maybe then, we won't get fooled again.

\section{Acknowledgments}

I have had the pleasure of sharing different parts and versions of this essay with many groups and individuals, and in each case I have learned something new. My special thanks go to Don Bialostosky, Patricia Harkin, Russel Durst, Geoff Sirc, Lisa Ede, Phil Smith, Tom Fox, Richard Miller, Patricia Bizzell, Sharon Crowley, and Marilyn Cooper.

\section{Notes}

1. There is still no better account of how in the United States class issues get repressed and internalized, made to seem the failings of individuals rather than the workings of social structures, than Sennett and Cobb's 1972 Hidden Injuries of Class. 
2. In Token Professionals and Master Critics, James Sosnoski brilliantly analyzes the sense of anxious self-doubt that the academic system of ranking and sorting gives rise to in almost all its members.

3. Paul Fussel offers a hyperbolic example of this denial in his wishful description of artists, academics, and intellectuals as belonging to a special "category X" rather than a social class (212-23).

4. The 1999 "Report of the ADE Ad Hoc Committee on Staffing” documents patterns of staffing first-year courses which show that part-time and adjunct teachers can no longer be viewed as "temporary supplements" to the tenure-stream faculty but are rather "structurally required ... for institutions to offer all the courses they regularly need to offer in the undergraduate curriculum" (4). This report, drafted in the main by Philip Smith of the University of Pittsburgh, is remarkable for the evenhandedness of its tone, the clarity of its analysis, and the force of its recommendations.

5. An argument against such moves is that they will create a second-class faculty. My response is that we already have a third- or fourth-class faculty in place, that we need to recognize this fact, and that we should attempt to do better by these colleagues.

6. Jennifer Seibel Trainor and Amanda Godley detail the effects of such cynical uses of outsourcing in their recent $C C C$ essay, "After Wyoming: Labor Practices in Two University Programs."

7. See Crowley's Composition in the University and also the essays in Joseph Petraglia's Reconceiving Writing, Rethinking Writing Instruction. For a powerful counter to the "New Abolitionism," see Roemer, Schultz, and Durst's recent essay on "Reframing the Great Debate on First-Year Writing."

8. See Mary Soliday's "From the Margins to the Mainstream" and Rhonda Grego and Nancy Thompson's "Repositioning Remediation" for compelling examples of such work.

9. See Royer and Gilles's intriguing CCC essay "Directed Self-Placement."

10. This case is made powerfully in the eloquent but overlooked MLA report on "Making Faculty Work Visible," which argues for a view of teaching, service, and scholarship, not as different forms of work but rather as varying sites where intellectual work of high caliber can take place.

\section{Works Cited}

Bartholomae, David. "Freshman English, Composition, and CCCC." College Composition and Communication 40 (1989): 38-50.
Bourdieu, Pierre. Distinction: A Social Critique of the Judgement of Taste. Trans. Richard Nice. Cambridge: Harvard UP, 1984. 
Burke, Kenneth. A Rhetoric of Motives. Berkeley: U of California P, 1969.

Crowley, Sharon. Composition in the University: Historical and Polemical Essays. Pittsburgh: U of Pittsburgh P, 1998.

Drew, Julie. "The Discourse of Academic Reform and the Myth of the Universal Teacher-Subject." Composition Forum 8.1 (1997): 10-20.

Ehrenreich, Barbara. Fear of Falling: The Inner Life of the Middle Class. New York: Harper, 1990.

"Final Report of the MLA Committee on Professional Employment." PMLA 113 (1998): 1154-77.

Fox, Tom. Defending Access: A Critique of Standards in Higher Education. Portsmouth, NH: HeinemannBoynton/Cook, 1999.

Franklin, Phyllis. "Setting Standards: Acceptable Ratios of Full-to Part-Time Faculty Members." MLA Newsletter (Fall 1998): 5-6.

Fussel, Paul. Class. New York: Ballantine, 1983.

Grego, Rhonda, and Nancy Thompson. "Repositioning Remediation: Renegotiating Composition's Work in the Academy." College Composition and Communication 47 (1996): 62-84.

Gunner, Jeanne. “The Fate of the Wyoming Resolution: A History of Professional Seduction." Writing Ourselves into the Story: Unheard Voices from Composition Studies. Ed. Sheryl I. Fontaine and Susan Hunter. Carbondale: Southern Illinois UP, 1993. 107-22.

Hairston, Maxine. "Breaking Our Bonds and Reaffirming Our Connections." College Composition and Communication 36 (1985): 272-82.
Horner, Bruce. Terms of Work for Composition: A Materialist Critique. Albany: SUNY P, 2000.

James, Henry. The Turn of the Screw. 1898. New York: Dover, 1991.

Kovacic, Kristin. "'Proud to Work for the University." Women's Studies Quarterly (Spring/Summer 1995): 19-24.

"Making Faculty Work Visible: Reinterpreting Professional Service, Teaching, and Research in the Fields of Language and Literature." Profession 96: 161-216.

Miller, Richard E. As If Learning Mattered: Reforming Higher Education. Ithaca: Cornell UP, 1998.

. "Let's Do the Numbers: Comp Droids and the Prophets of Doom." Profession 1999: 96-105.

Miller, Susan. Textual Carnivals: The Politics of Composition. Carbondale: Southern Illinois UP, 1991.

Murphy, Michael. "New Faculty for a New University: Toward a Full-Time TeachingIntensive Faculty Track in Composition." College Composition and Communication 52 (2000): 14-42.

Nelson, Cary. "Lessons from the Job Wars: What Is to Be Done?" Academe (Nov.-Dec. 1995): 18-25.

"What Hath English Wrought: The Corporate University's Fast Food Discipline." MLA Workplace Web Site. workplace-gsc.com/workplace1/ workplace.html/ June 2000.

Olson, Gary A., and Joseph M. Moxley. "Directing Freshman Composition: The Limits of Authority." College Composition and Communication 40 (1989): 51-60.

Petraglia, Joseph, ed. Reconceiving Writing, Rethinking Writing Instruction. Mahwah, NJ: Erlbaum, 1995. 
"Report of the ADE Ad Hoc Committee on Staffing." ADE Bulletin 122 (Spring 1999): 7-26.

Roemer, Marjorie, Lucille M. Schultz, and Russel K. Durst. "Reframing the Great Debate on First-Year Writing." College Composition and Communication 50 (1999): 377-92.

Royer, Daniel J., and Roger Gilles. "Directed Self-Placement: An Attitude of Orientation." College Composition and Communication 50 (1998): 54-70.

Schackner, Bill. "Colleges Farm Out-to a Degree.” Pittsburgh Post-Gazette 6 Sept. 1998: E8.

Schell, Eileen. Gypsy Academics and MotherTeachers: Gender, Contingent Labor, and Writing Instruction. Portsmouth, $\mathrm{NH}$ : Heinemann-Boynton/Cook, 1998.

Sennett, Richard, and Jonathan Cobb. The Hidden Injuries of Class. New York: Vintage, 1972.

Shepard, Alan, John McMillan, and Gary Tate, eds. Coming to Class: Pedagogy and the Social Class of Teachers. Portsmouth, NH: Heinemann-Boynton/Cook, 1998.
Sledd, James. "Why the Wyoming Resolution Had to Be Emasculated: A History and a Quixoticism." JAC 11 (1991): 269-81.

Soliday, Mary. "Class Dismissed." College English 61 (1999): 731-41.

—. "From the Margins to the Mainstream: Reconceiving Remediation." College Composition and Communication 47 (1996): 85-100.

Sosnoski, James. Token Professionals and Master Critics: A Critique of Orthodoxy in Literary Studies. Albany: SUNY P, 1994.

"Statement of Principles and Standards for the Postsecondary Teaching of Writing." College Composition and Communication 40 (1989): 329-36.

Thompson, E. P. The Making of the English Working Class. New York: Vintage, 1966.

Trainor, Jennifer Seibel, and Amanda Godley. "After Wyoming: Labor Practices in Two University Writing Programs." College Composition and Communication 50 (1998): 153-81.

\section{Joseph Harris}

Joseph Harris directs the Center for Teaching, Learning, and Writing at Duke University. He is the author of $A$ Teaching Subject: Composition since 1966 (Prentice, 1997) and Media Journal: Reading and Writing about Popular Culture (Allyn and Bacon, 1999). From 1994-99, Harris also edited CCC. 